\title{
GAMBARAN PENDEKATAN PEMBELAJARAN BIOLOGI KURIKULUM 2013 DI SMA SWASTA SE-KABUPATEN PURWOREJO
}

\author{
Fajar Adinugraha $^{1 *}$; Adisti Ratnapuri $^{2)}$, Andriyan Ino Ponto ${ }^{3)}$, Novalina ${ }^{4)}$ \\ 1).Pendidikan Biologi, FKIP-UKI;fadinugraha0608@gmail.com \\ 2).Pendidikan Biologi, FKIP-UKI; adistiratnapuri@gmail.com, \\ ${ }^{3)}$ Pendidikan Biologi, FKIP-UKI; andryanponto@ gmail.com, \\ ${ }^{4)}$ Pendidikan Biologi, FKIP-UKI; novalinasimanullang@gmail.com.
}

\begin{abstract}
The purpose of this study was to determine the description of the Biology learning approach applied in private high schools throughout Purworejo Regency and the factors that support and hinder the learning activities of Biology with the learning approach in private high schools throughout Purworejo Regency. Research methods are surveys and interviews related to the Biology Learning approach conducted in private high schools throughout Purworejo Regency. The research instrument was a non-test instrument and the data obtained were qualitative and quantitative data in the form of Biology National Examination (UN) scores which were analyzed using descriptive statistics. The results obtained are (1). The approach used in Biology Learning in private high schools throughout Purworejo Regency is the Scientific Approach and the Natural Exploration Approach, while the Local Wisdom and Cultural Approach is rarely used. (2). Biology National Examination (UN) scores do not depend on the applied learning approach. This is because the learning outcomes of the Biology UN which are the benchmarks in this study cannot be used as a description of student learning outcomes (cognitive, affective, psychomotor) as a whole. (3). Factors that support and hinder the process of implementing the learning approach are the learning process, motivation, time and the ability of students..
\end{abstract}

Keywords: learning approach; Biology; Curriculum 2013; Purworejo

\begin{abstract}
ABSTRAK
Tujuan penelitian ini adalah untuk mengetahui gambaran pendekatan pembelajaran Biologi yang diterapkan di SMA Swasta se-Kabupaten Purworejo dan faktor yang mendukung dan menghambat kegiatan pembelajaran Biologi dengan pendekatan pembelajaran di SMA Swasta se-Kabupaten Purworejo. Metode Penelitian adalah survey dan wawancara terkait pendekatan Pembelajaran Biologi yang dilakukan di SMA Swasta se-Kabupaten Purworejo. Instrumen penelitian adalah instrumen non test dan data yang diperoleh adalah data kualitatif dan kuantitatif berupa nilai UjianNasional (UN) Biologi yang dianalisis menggunakan statistik deskriptif. Hasil yang diperoleh adalah (1). Pendekatan yang digunakan dalam Pembelajaran Biologi di SMA Swasta se-Kabupaten Purworejo adalah Pendekatan Saintifik dan Pendekatan Jelajah Alam Sekitar sedangkan Pendekatan Kearifan Lokal dan Budaya jarang digunakan. (2). Nilai Ujian Nasional (UN) Biologi tidak bergantung pada Pendekatan Pembelajaran yang diterapkan. Hal ini karena hasil belajar UN Biologi yang menjadi tolak ukur pada penelitian ini tidak dapat digunakan sebagai gambaran hasil belajar peserta didik (koginitif, afektif, psikomotorik) secara keseluruhan. (3). Faktor yang mendukung dan menghambat proses pelaksanaan pendekatan pembelajaran adalah proses pembelajaran, motivasi, waktu dan kemampuan peserta didik.
\end{abstract}

Keywords: Pendekatan Pembelajaran; Biologi; Kurikulum 2013; Purworejo 


\section{PENDAHULUAN}

Kualitas atau mutu suatu pendidikan dapat dinilai dari kompetensi lulusan (Idrus, 2010). Kompetensi lulusan dapat dilihat dari hasil belajar yang sesuai kompetensi Kurikulum 2013, antara lain: nilai sikap spiritual, nilai sikap sosial, nilai sikap pengetahuan, dan sikap keterampilan. Hasil belajar secara klasikal juga dapat dilihat melalui nilai Ujian Nasional (UN) karena mutu pendidikan juga bisa diliihat dari nilai UN (Safari, 2015), tentunya pada penelitian ini dititikberatkan pada nilai UN Biologi. Meskipun demikian, Ujian Nasional pada tahun 2020 sudah dihentikan (dalam kondisi Pandemi Covid-19) dan akan diganti dengan Asesmen Kompetensi Minimum (AKM) pada tahun 2021.

Berdasarkan hasil UN Biologi SMA Negeri dan Swasta yang diambil dari (Pusat Penilaian Pendidikan Kemdikbud, 2020), Kabupaten Purworejo selalu berada di peringkat 10 besar nilau UN Biologi dari 35 kabupaten/kota di Jawa Tengah. Secara berturut-turut dari tahun ajaran 2016/2017, 2017/2018, dan 2018/2019 adalah peringkat 8 (rata-rata 62.63), peringkat 7 (rata-rata 65.17), dan peringkat 6 (rata-rata 65.02) di mana nilai rata-rata UN Biologi di Kabupaten Purworejo selalu berada di atas rata-rata nilau UN Biologi Jawa Tengah.

Selanjutnya, apabila dilihat data per Kabupaten Purworejo maka terdapat sekitar 19-20 SMA Negeri dan Swasta yang menyelenggarakan UN Biologi (mengingat tidak semua SMA menyelenggarakan UN Biologi, tergantung peserta UN dalam memilih mata uji IPA). Berdasarkan data, rerata nilai UN Biologi SMA Negeri di Purworejo lebih tinggi dibandingkan SMA Swasta. Rerata nilai UN Biologi SMA Negeri secara berturutturut dari tahun ajaran 2016/2017, 2017/2018, dan 2018/2019 adalah 64.25; 68.37; dan 66.06. Rerata nilai UN Biologi SMA Swasta secara berturut-turut dari tahun ajaran 2016/2017, 2017/2018, dan 2018/2019 adalah 50.18; 53.52; dan 53.46. Berdasarkan data tersebut, rerata nilai UN Biologi SMA Swasta di Purworejo lebih rendah dibandingkan rerata UN Biologi Kabupaten Purworejo.

Faktor pendorong rendahnya nilai UN, antara lain dari (1) faktor internal, meliputi minat motivasi belajar dan kurangnya minat baca; serta (2) faktor eksternal meliputi faktor keluarga dan faktor sekolah (kurikulum dan sarana prasarana) (Setiawan, Melia and Rahayu, 2016). Berdasarkan faktor pendorong tersebut, peneliti ingin melihat dari sisi faktor sekolah lebih tepatnya pada pelaksanaan Kurikulum 2013. Hal ini karena apabila pengelolaan pembelajaran kurang tepat maka dapat menurunkan tingkat penguasaan materi (Hanurani, 2019). Dengan diketahuinya faktor pengelolaan pembelajaran, diharapkan 
dapat memberikan masukan bagi sekolah terutama sekolah swasta untuk lebih berkembang mengingat sekolah swasta merupakan salah satu pendukung pendidikan di Indonesia. Tanpa adanya sekolah swasta, pemerintah tidak akan mampu memenuhi fasilitas pendidikan bagi semua masyarakat.

Salah satu bentuk pengelolaan pembelajaran adalah melalui pendekatan pembelajaran. Pemilihan pendekatan pembelajaran yang tepat dapat meningkatkan hasil belajar peserta didik (Turdjai, 2014). Pendekatan pembelajaran merupakan wawasan atau sudut pandang yang dirumuskan dan dilandaskan pada prinsip pembelajaran dan teori pembelajaran (Alimah and Aditya, 2016). Pendekatan pembelajaran merupakan cara pandang dalam memilih kegiatan pembelajaran di mana setiap pendekatan ini memiliki karakteristik dan tujuan tertentu yang berbeda satu dengan lainnya (Lutvaidah, 2016). Dalam memilih sebuah pendekatan, guru harus menyesuaikan dengan kondisi dan tujuan yang akan dicapai. Pendekatan Saintifik menjadi salah satu pendekatan yang disarankan dalam Kurikulum 2013.

Pendekatan Saintifik merupakan pendekatan yang mengedepankan Keterampilan Proses Sains peserta didik. Keterampilan Proses Sains, meliputi keterampilan: mengobservasi (menghitung, mengukur, mengklasifikasi), merusmuskan masalah, membuat hipotesis, mengidentifikasi variabel dan mendefinisikan secara operasional variabel tersebut, merencanakan penelitian dengan prosedur yang tepat, analisis, intrepretasi, inferensi, dan mengomunikasikan hasil (Verawati, Prayogi and Asy'ari, 2014). Keterampilan Proses Sains ini tertuang lebih sederhana dalam Pendekatan Saintifik (Agustina, 2017).

Pendekatan Pembelajaran yang menjadi ciri khas Biologi lainnya, yaitu Pendekatan Jelajah Alam Sekitar (JAS). Pendekatan Jelajah Alam Sekitar merupakan pendekatan pembelajaran yang memanfaatkan alam sekitar dengan mengutamakan Keterampilan Proses Sains. Pendekatan JAS dapat dikatakan sebagai pendekatan dengan pemanfaatan lingkungan alam di sekitar tempat tinggal peserta didik baik itu lingkungan fisik, sosial, teknologi, dan budaya yang dijadikan obyek belajar sendiri dan dipelajari dengan kerja ilmiah (Alimah and Aditya, 2016).

Pendekatan Jelajah Alam Sekitar (JAS) dapat digunakan sebagai alternatif pendekatan pembelajaran dalam pembelajaran Biologi. Hal ini karena Pendekatan JAS mampu mengajak peserta didik untuk mengembangkan Keterampilan Proses Sains menggunakan langkahlangkah metode ilmiah. Selain itu, obyek kajian Biologi mengenai keanekaragaman hayati (hewan, tumbuhan, jamur, Protista, 
bakteri) termasuk manusia dan pemanfaatan teknologi dibutuhkan pendekatan yang memberikan kesempatan peserta didik untuk melihat langsung lingkungan sekitar.

Pendekatan lainnya yang juga bisa diterapkan adalah Pendekatan Kearifan Lokal dan Budaya (KALBU). Pendekatan Kearifan Lokal dan Budaya merupakan pendekatan pembelajaran yang mengaitkan pengetahuan kearifan lokal dan budaya dengan mata pelajaran Biologi (kompetensi sikap spiritual, kompetensi sikap sosial, kompetensi pengetahuan, dan kompetensi keterampilan). Nilai-nilai luhur dan pengetahuan dalam kearifan lokal dan budaya dapat dijadikan alternatif sebagai referensi sumber belajar (Adinugraha, 2018b) yang akan memudahkan peserta didik untuk mengkonstruksi konsep sain modern dengan tetap menjaga kearifan lokal dan budaya (Pieter, 2016).

Pelaksanaan pembelajaran Biologi seyogyanya menggunakan pendekatan pembelajaran yang berpusat pada peserta didik dan mengutamakan berpikir ilmiah. Oleh karena itu, Kurikulum 2013 yang sudah berlangsung 6-7 tahun akan dilakukan analisis untuk mengetahui gambaran pelaksanaan pembelajaran Biologi menggunakan pendekatan pembelajaran yang sudah dilakukan. Penelitian dilakukan dengan menganalisis pembelajaran dari sisi peserta didik dan guru.
Berdasarkan uraian di atas, tujuan penelitian ini antara lain: 1) untuk mengetahui gambaran pendekatan pembelajaran Biologi yang diterapkan di SMA Swasta se-Kabupaten Purworejo dan 2) untuk mengetahui faktor yang mendukung dan menghambat kegiatan pembelajaran Biologi dengan pendekatan pembelajaran di SMA Swasta seKabupaten Purworejo. Dengan mengetahui gambaran pelaksanaan pendekatan pembelajaran Kurikulum 2013, diharapkan dapat memberikan kontribusi kepada sekolah penelitian untuk memberikan alternatif pendekatan pembelajaran yang sesuai dengan kondisi sekolah.

\section{METODE PENELITIAN}

Metode penelitian adalah survei dan wawancara dengan tahapan penelitian dimodifikasi penulis sebagai berikut.

1. Prosedur pertama merupakan tahap meliputi: studi pendahuluan, kajian literatur, dan pembuatan proposal. Prosedur pertama ini disebut juga prapenelitian dengan melakukan observasi awal.

2. Prosedur kedua merupakan tahap yang meliputi pembuatan instrumen. Instrumen tersebut, meliputi Kuesioner Gambaran pelaksanaan pendekatan pembelajaran Biologi di SMA bagi peserta didik, (b) Lembar wawancara tentang kendala pelaksanaan pendekatan pembelajaran bagi guru, dan (c) Kuesioner kendala 
pembelajaran Biologi bagi peserta didik.

3. Prosedur ketiga merupakan tahap validasi instrumen. Instrumen bisa divalidasi penelitian dapat dilakukan dengan dua cara, yaitu secara formal dan faktual. Formal dapat dilakukan dengan konsultasi pada ahli di bidangnya, sedangkan faktual bisa dilakukan dengan uji coba instrumen tersebut di lapangan pada kelompok yang setara. Pada penelitian ini, instrumen diujikan kepada ahlidi bidangnya atau validator. Selanjutnya, dilakukan revisi sebelum digunakan di lapangan. Instrumen berupa kuesioner dilakukan uji validasi kepada ahli/dosen, yaitu Niken Kusumarini, M.Si. (Universitas Islam Negeri Walisongo, Semarang) dan Sulasfiana Alfi Raida (Institut Agama Islam Negeri Kudus)

4. Prosedur keempat merupakan tahap pengambilan data di sekolah sampel. Data tersebut diambil dengan metode survei (observasi, kuesioner, wawancara). Populasi diambil dari penentuan nilai UN Biologi selama 3 tahun di SMA Swasta se-Kabupaten Purworejo. Selanjutnya, cluster SMA Swasta itu dikelompokkan ke dalam 2 level, yaitu level tinggi dan rendah. Pada level tinggi (A) diambil 3 sekolah dan pada level rendah (B) diambil 3 sekolah sehingga diperoleh sampel
$50 \%$ dari populasi. Pengambilan sekolah juga memerhatikan wilayah Kecamatan yang diambil. Oleh karena itu, teknik pengambilan sampel adalah Cluster Random Sampling. Berdasarkan data tersebut diambil 3 sampel sekolah, yaitu SMA Bruderan Purworejo, SMA Pius Bakti Utama Bayan, SMA Pancasila Purworejo, SMA Muhamadiyah Purworejo, SMA Widya Kutoarjo, dan SMA Islam Sudirman Bruno. Data diambil sebanyak 106 responden yang tersebar di 6 (enam) sekolah dengan metode daring (google form) dan tatap muka disesuaikan dengan kondisi sekolah.

Tabel 1.Data Nilai Rerata Ujian Nasional Biologi SMA Swasta yang melaksanakan UN Biologi 3 tahun terakhir Kabupaten Purworejo*

\begin{tabular}{|c|c|c|}
\hline $\begin{array}{l}\text { Kate } \\
\text { gori }\end{array}$ & Nama Sekolah & $\begin{array}{l}\text { Rerata UN } \\
\text { Biologi }\end{array}$ \\
\hline \multirow{5}{*}{ 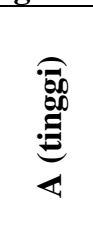 } & SMA Bruderan Purworejo & 60.93 \\
\hline & SMA Pius Bakti Utama & 57.14 \\
\hline & Bayan & \\
\hline & SMA Pancasila Purworejo & 55.67 \\
\hline & $\begin{array}{ll}\text { SMA } & \text { Muhammadiyah } \\
\text { Kutoario } & \end{array}$ & 53.55 \\
\hline \multirow{6}{*}{ 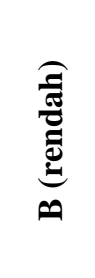 } & $\begin{array}{lll}\text { SMA } & \text { Darul Hikmah }\end{array}$ & 53.54 \\
\hline & Kutoarjo & \\
\hline & Muhammadiyah & 49.14 \\
\hline & Purworejo & \\
\hline & SMA Widya Kutoarjo & 45.41 \\
\hline & $\begin{array}{l}\text { SMA Islam Sudirman } \\
\text { Bruno }\end{array}$ & 44.26 \\
\hline *) & Penilaian & Pendidika \\
\hline
\end{tabular}

5. Prosedur kelima merupakan tahap analisis data di mana menggunakan deskripsi kuantitatif dan kualitatif. Deskripsi kuantitatif (studi deksriptif) bertujuan untuk menggambarkan 
kondisi maupun sikap yang menjelaskan dan mencatat kondisi yang sedang terjadi pada waktu tertentu (Morissan, 2012). Metode penelitian deskriptif dalam bentuk survei dapat digunakan untuk melihat problema terhadap suatu status fenomena dan mendiskripsikannya (Anggito and Setiawan, 2018). Penelitian deskriptif dapat digunakan untuk menjelaskan di bidang pendidikan dan kurikulum (Hamdi and Bahruddin, 2014). Oleh karena penelitian ini bertujuan untuk melihat gambaran umum pendekatan pembelajaran, maka metode yang dirasa tepat adalah survei dan wawancara yang kemudian diolah menggunakan statistika deskriptif dan kualitatif.Data kuesioner ditabulasikan, kemudian dihitung jumlah skor kriterium dan skor hasil pengamatan yang kemudian dibuat garis kontinuum skor minimal dan skor maksimal yang selanjutnya dihitung presentase dari kriteria yang ditetapkan (Sugiyono, 2019). Selanjutnya, deskripsi Kualitatif dilakukan untuk mendeskripsikan hasil wawancara dan faktor yang mendukung dan menghambat pendekatan pembelajaran Biologi.

\section{HASIL DAN PEMBAHASAN}

Hasil dan pembahasan meliputi: 1) Deskripsi statistik gambaran pendekatan pembelajaran biologi SMA Swasta di Kabupaten Purworejo dan 2) Faktor yang mendukung dan menghambat pelaksanaan pembelajaran Biologi.

\section{Deskripsi Pendekatan Pembelajaran Biologi SMA Swasta di Kabupaten Purworejo.}

Hasil survei dilakukan di 6 (enam) SMA Swasta dengan total responden berjumlah 106 peserta didik dari kelas X MIPA dan XI MIPA dengan teknik sampling yang sudah dijelaskan pada sub bab sebelumnya. Kuesioner diberikan kepada peserta didik melalui google form dan tatap muka mengingat kondisi Pandemi Covid-19 yang mengharuskan beberapa sekolah belajar dari rumah. Namun, ada beberapa yang secara tatap muka dengan pengambilan data menggunakan protokol kesehatan.

Pengambilan data dilakukan dari tanggal 1 September - 25 Oktober 2020. Instrumen berupa kuesioner ini terdiri atas 85 pertanyaan dengan rincian antara lain: 7 pertanyaan kegiatan pendahuluan, 30 pertanyaan kegiatan inti: Pendekatan Saintifik, 23 pertanyaan kegiatan inti: Pendekatan Jelajah Alam Sekitar, 26 pertanyaan kegiatan inti: Pendekatan Kearifan Lokal dan Budaya, dan 5 pertanyaan kegiatan penutup.

Sebelum kuesioner diberikan kepada responden, dilakukan uji validasi instrumen terlebih dahulu kepada 2 (dua) orang validator. Berdasarkan hasil uji validasi, instrumen dinyatakan sangat valid dengan skor 89.09. Validasi desain ini 
diperlukan untuk menilai rancangan suatu produk terutama instrumen baik secara rasional agar efektif yang dilakukan oleh pakar atau tenaga ahli atau dapat dilakukan melalui diskusi (Sugiyono, 2019). Hasil survei tersebut kemudian dianalisis dengan jumlah skor kriterium dan skor hasil pengumpulan data dengan rumus dari Buku Sugiyono 2019 berjudul Metode Penelitian Kuantitatif, Kualitatif, dan R and D. Hasil analisis disajikan pada Gambar 1 dan 2.

Berdasarkan Gambar 1, responden memberikan pernyataan bahwa Kualitas
Pendekatan Pembelajaran di SMA Swasta se-Kabupaten Purworejo adalah $85.66 \%$ dari kriteria yang ditetapkan atau berada kriteria baik. Selanjutnya, apabila dianalisis responden tiap SMA memberikan respon, yaitu $83.79 \%$ (SMA Bruderan Purworejo); $87.18 \%$ (SMA Pancasila Purworejo); 84.49\% (SMA Pius Bakti Utama Bayan, Purworejo); 87.54\% (SMA Islam Sudirman Bruno, Purworejo); 86.90\% (SMA Muhammadiyah Purworejo); dan $82.67 \%$ (SMA Widya Kutoarjo, Purworejo).

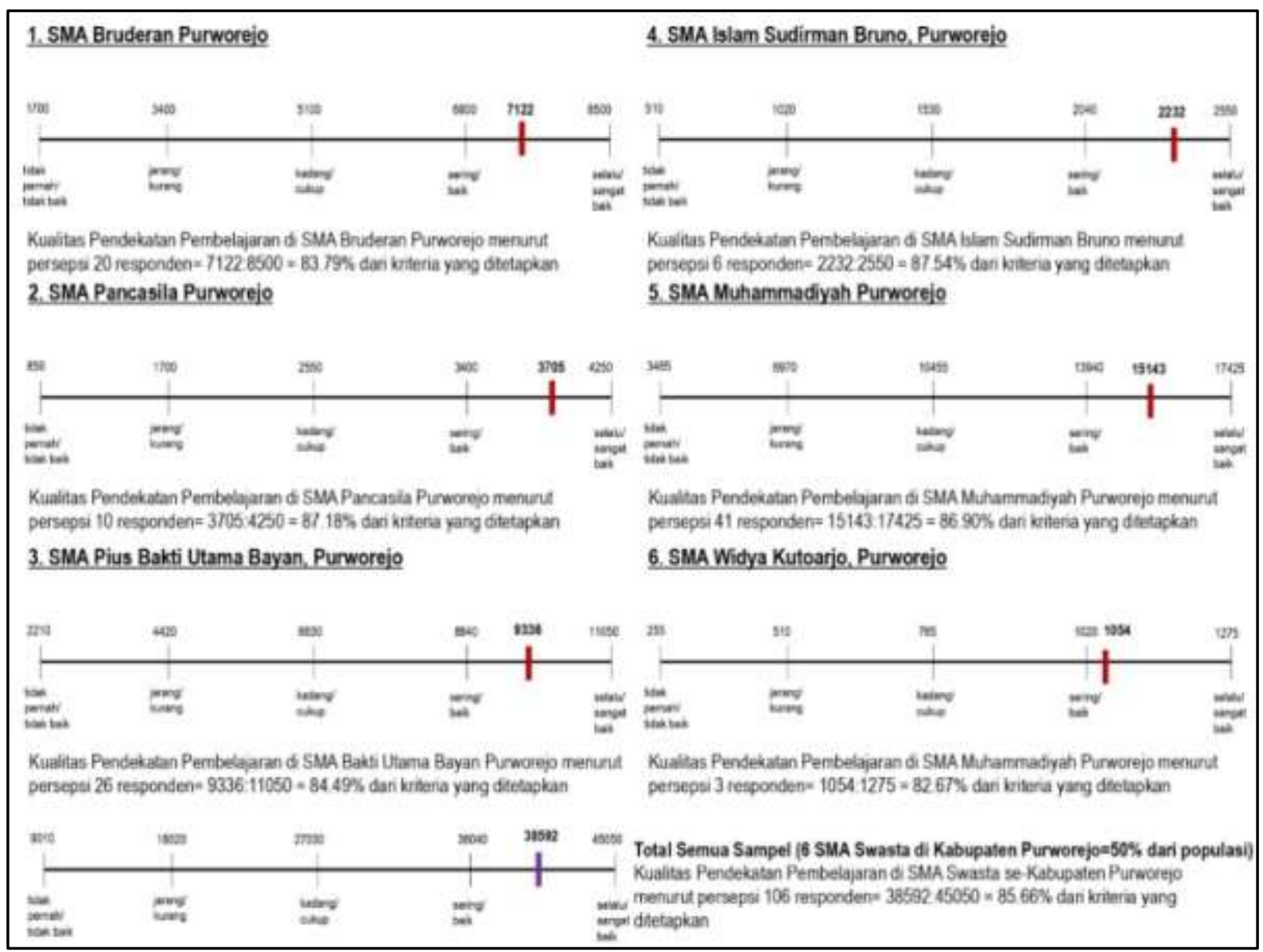

Gambar 1. Persepsi Peserta didik terhadap Kualitas Pelaksanaan Pendekatan Pembelajaran tiap sampel sekolah dan total semua sampel SMA Swasta di Kabupaten Purworejo. 
Semua responden di setiap SMA memberikan respon baik terhadap kualitas Pendekatan Pembelajaran dengan respon persentase yang bervariasi. Respon yang bervariasi tiap sekolah karena faktor internal dan eksternal yang berbeda setiap sekolah. Faktor yang memengaruhi belajar (pembelajaran), yaitu faktor internal (kondisi jasmani dan rohani, kematangan/pertumbuhan, kecerdasan, minta, latian dan kebiasaan belajar, motivasi pribadi dan konsep diri) serta faktor eksternal (pendekatan pembelajaran, guru dan cara mengajarnya, kesempatan yang tersedia, dan motivasi sosial) (Syarifuddin, 2011). Pendekatan pembelajaran yang dilakukan oleh setiap guru di sekolah penelitian umumnya menggunakan Pendekatan Saintifik dan Jelajah Alam Sekitar, sedangkan Pendekatan Kearifan Lokal dan Budaya jarang digunakan Tabel 2.

Tabel 2. Persepsi Peserta didik terhadap Pelaksanaan Pendekatan Pembelajaran Biologi dan Data Hasil UN sekolah sampel

\begin{tabular}{|c|c|c|c|c|c|c|c|c|c|}
\hline \multirow[b]{3}{*}{ No } & \multirow[b]{3}{*}{$\begin{array}{l}\text { Kate } \\
\text { gori } \\
\text { Nilai } \\
\text { UN }\end{array}$} & \multirow[b]{3}{*}{ Nama SMA } & \multicolumn{5}{|c|}{ Jenis Kegiatan/Pendekatan } & \multirow{3}{*}{$\begin{array}{l}\text { Rerata Skor } \\
\text { (Persepsi } \\
\text { Peserta } \\
\text { didik } \\
\text { terhadap } \\
\text { Pendekatan } \\
\text { Pembelajar } \\
\text { an Biologi) }\end{array}$} & \multirow[b]{3}{*}{$\begin{array}{l}\text { Rerata } \\
\text { Nilai UN } \\
\text { Biologi } \\
\text { (2016- } \\
\text { 2019) }\end{array}$} \\
\hline & & & \multirow[b]{2}{*}{$\begin{array}{l}\text { Penda } \\
\text { huluan }\end{array}$} & \multicolumn{3}{|c|}{ Inti } & \multirow[b]{2}{*}{ Penutup } & & \\
\hline & & & & Saintifik & $\begin{array}{l}\text { Jelajah } \\
\text { Alam } \\
\text { Sekitar }\end{array}$ & $\begin{array}{l}\text { Kearifa } \\
\text { n } \\
\text { Lokal } \\
\text { dan } \\
\text { Budaya }\end{array}$ & & & \\
\hline 1 & & $\begin{array}{l}\text { SMA Bruderan } \\
\text { Purworejo }\end{array}$ & $91.86 \%$ & $82.53 \%$ & $79.78 \%$ & $67.04 \%$ & $85.00 \%$ & $83.79 \%$ & 60.93 \\
\hline 2 & : & $\begin{array}{l}\text { SMA Pius Bakti } \\
\text { Utama Bayan }\end{array}$ & $93.63 \%$ & $83.92 \%$ & $81.14 \%$ & $65.89 \%$ & $85.85 \%$ & $84.49 \%$ & 57.14 \\
\hline 3 & $\overparen{\Xi}$ & $\begin{array}{l}\text { SMA Pancasila } \\
\text { Purworejo }\end{array}$ & $91.14 \%$ & $84.53 \%$ & $85.04 \%$ & $70.23 \%$ & $90.80 \%$ & $87.18 \%$ & 55.67 \\
\hline 4 & & $\begin{array}{l}\text { SMA } \\
\text { Muhammadiyah } \\
\text { Purworejo }\end{array}$ & $91.85 \%$ & $84.80 \%$ & $85.22 \%$ & $68.95 \%$ & $89.46 \%$ & $86.90 \%$ & 49.14 \\
\hline 5 & 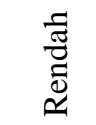 & $\begin{array}{ll}\text { SMA Islam } \\
\text { Sudirman } \\
\text { Bruno }\end{array}$ & $93.33 \%$ & $82.78 \%$ & $84.78 \%$ & $72.44 \%$ & $94.00 \%$ & $87.53 \%$ & 45.41 \\
\hline 6 & $\widehat{\vartheta}$ & $\begin{array}{l}\text { SMA Widya } \\
\text { Kutoarjo }\end{array}$ & $92.38 \%$ & $82.67 \%$ & $76.23 \%$ & $66.41 \%$ & $84.00 \%$ & $82.67 \%$ & 44.26 \\
\hline $\begin{array}{l}\text { Rer } \\
\text { didi } \\
\text { Keg } \\
\text { Bio }\end{array}$ & $\begin{array}{r}\text { a Skor } \\
\text { te } \\
\text { tan }\end{array}$ & $\begin{array}{l}\text { Persepsi Peserta } \\
\text { ladap tahap } \\
\text { Pembelajaran } \\
\text { mponen) }\end{array}$ & $92.32 \%$ & $83.96 \%$ & $82.90 \%$ & $68.08 \%$ & $87.96 \%$ & $85.66 \%$ & 52.092 \\
\hline
\end{tabular}

Berdasarkan wawancara dengan guru matapelajaran Biologi di sekolah sampel penelitian, karateristik Pendekatan Pembelajaran ini juga dipengaruhi oleh sarana pendidikan dan kemampuan guru dalam memanfaatkan sarana tersebut.
Sarana pendidikan merupakan berbagai peralatan yang digunakan oleh guru yang digunakan untuk memudahkan penyampaian materi pelajaran secara langsung seperti: ruang, buku, perpustakaan, dan laboratorium (Prasatyawan, 2016). Sarana yang dikelola 
dengan baik akan menampilkan kenyamanan, keindahan, kemutakhiran, dan kemudahan dalam penggunaanya (Mukhroji, 2015) sehingga akan memperlancar proses pembelajaran. Selain pengelolaan oleh sekolah, guru juga perlu memiliki kemampuan untuk menggunakan sarana tersebut. Pada alinea berikut, akan dijelaskan karakteristik pembelajaran tiap sekolah. Umumnya, semua SMA Swasta di Kabupaten Purworejo memiliki sarana yang lengkap tetapi pemanfaatanya yang kurang maksimal.

SMA Bruderan Purworejo. Pembelajaran di SMA ini tidak terpaku pada buku paket pelajaran. Namun, guru memberikan pengalaman belajar dengan Pendekatan Saintifik dan Jelajah Alam Sekitar. Pemanfaatan green house sebagai pembelajaran juga sering dilakukan. Di sekolah, terdapat akuarium yang cukup besar untuk memelihara ikan terutama ikan khas yang ada di Sungai Bogowonto Kabupaten Purworejo. Di bagian samping, sekolah juga terdapat kebun singkong yang bisa dimanfaatkan untuk sayur peserta didik-peserta didik dari panti asuhan dan asrama. SMA ini juga memiliki laboratorium yang lengkap dan kolam ikan untuk memelihara ikan di samping laboratorium. Kolam ini selain untuk pelajaran Biologi juga digunakan untuk pelajaran kewirausahaan sehingga terjadi pembelajaran yang terintegrasi. Sekolah ini juga dilengkapi dengan asrama peserta didik. Berdasarkan pengamatan dan wawancara dengan guru Biologi, jauh sebelum Kurikulum 2013 dilaksanakan, guru mendorong pembelajaran berbasis Keterampilan Proses Sains (saintifik) dan Jelajah Alam Sekitar. Pembelajaran dengan Pendekatan Kearifan Lokal dan Budaya hanya sebatas pengenalan fauna khas Purworejo seperti ikan Sogo yang ditemukan di Kali Bogowonto dan kambing Peranakan Etawa.

SMA Pancasila Purworejo. Pembelajaran di SMA ini juga sudah menerapkan Pendekatan Saintifik dan Jelajah Alam Sekitar. Pemanfaatan laboratorium yang kurang maksimal karena terkendala masalah teknis. Namun, guru dengan segala kreativitasnya mampu memanfaatkan lingkungan sekitar dengan meminta anak mengamati tanaman di taman depan kelas. Sekolah ini juga dilengkapi dengan asrama peserta didik. Guru juga memberikan kesempatan peserta didik untuk diskusi. Berdasarkan penagamatan dan wawancara dengan guru Biologi, pembelajaran Biologi juga masih menggunakan pembelajaran ceramah plus tanya jawab. Hal ini disesuaikan dengan kondisi peserta didik di SMA tersebut sedangkan untuk Pendekatan Kearifan Lokal dan Budaya jarang diterapkan di SMA tersebut.

SMA Pius Bakti Utama. Pembelajaran di SMA ini juga sudah menitik beratkan pada Pendekatan 
Saintifik dan Jelalah Alam Sekitar. Laboratorium yang ada juga cukup lengkap dengan didukung oleh taman sekolah yang rindang dan asri meskipun lahan sekolah tidak begitu luas. Sekolah ini juga dilengkapi dengan asrama peserta didik. Berdasarkan hasil pengamatan dan wawancara, guru di SMA ini lebih menggunakan model ceramah plus, artinya guru menjelaskan dan berdiskusi dengan peserta didik ditambah tugas dan tanya jawab. Menurut narasumber, model tersebut sesuai diterapkan di SMA Pius dengan Pendekatan Saintifik dan Jelajah Alam Sekitar. Pendekatan Kearifan Lokal dan Budaya jarang diterapkan, hanya sebatas informasi mengenai keanekaragaman hayati.

SMA Islam Sudirman Bruno. SMA yang terletak di bagian utara dan jauh dari pusat kota ini memiliki karakteristik pembelajaran yang sedikit berbeda dari sekolah sampel lainnya. Letaknya yang di perbukitan membuat pembelajaran yang membutuhkan sinyal internet sangat jarang dilakukan. Namun, berdasarkan wawancara dan pengamatan dengan guru Biologi, Pendekatan Saintifik dan Jelalah Alam Sekitar sudah dilakukan tetapi tidak sering, sedangkan Pendekatan Kearifan Lokal dan Budaya jarang dilakukan. Laboratorium jarang digunakan dengan kondisi peralatan yang kurang maksimal. Namun, dalam kondisi yang terbatas guru selalu kreatif. Hal ini terbukti, dengan pemanfaatan lahan di samping sekolah yang digunakan untuk bercocok tanam. Pembelajaran bercocok tanam ini juga terintegrasi dengan kewirausahaan.

SMA Muhammadiyah Purworejo. SMA ini juga sudah menerapkan Pendekatan Saintifik dan Jelajah Alam Sekitar, tetapi untuk Pendekatan Kearifan Lokal dan Budaya jarang bahkan tidak pernah dilakukan. Berdasarkan wawancara dan pengamatan dengan guru Biologi, pemanfaatan laboratorium sudah terencana dengan baik dan dikelola dengan baik. Pembelajaran dengan model ceramah dan diskusi lebih efektif diterapkan di SMA tersebut. Taman di sekitar sekolah juga kadang dimanfaatkkan untuk pembelajaran Biologi.

SMA Widya Kutoarjo. SMA ini juga sudah menerapkan Pendekatan Saintifik dan Jelajah Alam Sekitar tetapi juga tidak pernah menerapkan Pendekatan Kearifan Lokal dan Budaya. Namun, dalam pelaksanaannya masih terkendala banyak kendala teknis. Kondisi peserta didik yang sedikit dan laboratorium yang kurang dikelola dengan baik sangat memengaruhi kegiatan pembelajaran. Namun, berdasarkan wawancara dan pengamatan, guru Biologi sangat antusias dengan segala keterbatasan tersebut.

Gambaran persepsi peserta didik terhadap kegiatan pembelajaran yang meliputi: kegiatan pendahuluan, kegiatan inti, dan kegiatan penutup disajikan pada 
Gambar 2. Kegiatan Pendahuluan dan Kegiatan Penutup mendapatkan penilaian yang baik oleh peserta didik yaitu $92,32 \%$ dan $87,96 \%$ dari kriteria yang ditetapkan yaitu $100 \%$. Kegiatan pendahuluan berupa apersepsi, motivasi, menyampaikan tujuan pembelajaran sedangkan kegiatan penutup berupa pembuatan kesimpulan (rangkuman), tes lisan, hasil kerja, dan arahan tindak lanjut kegiatan berikutnya (Erayati, 2014). Kegiatan Inti merupakan kegiatan utama pembelajaran di mana pendekatan pembelajaran nampak pada kegiatan inti tersebut. Kegiatan inti menekankan proses pembentukan pengalaman belajar peserta didik untuk mencapai kompetensi dengan berbagai kegiatan yang memperhatikan perkembangan fisik dan psikologis peserta didik (Santosa and Siregar, 2017). Guru sebaiknya selalu kreatif dan tidak hanya terpaku pada sintaks (tahapan) dalam pembelajaran sesuai tuntutan Kurikulum 2013. Pemberian ruang kreatif kepada guru dalam proses pembelajaran akan mendorong pembelajaran lebih kreatif (Biro Komunikasi dan Layanan Masyarakat Kemdikbud, 2016).

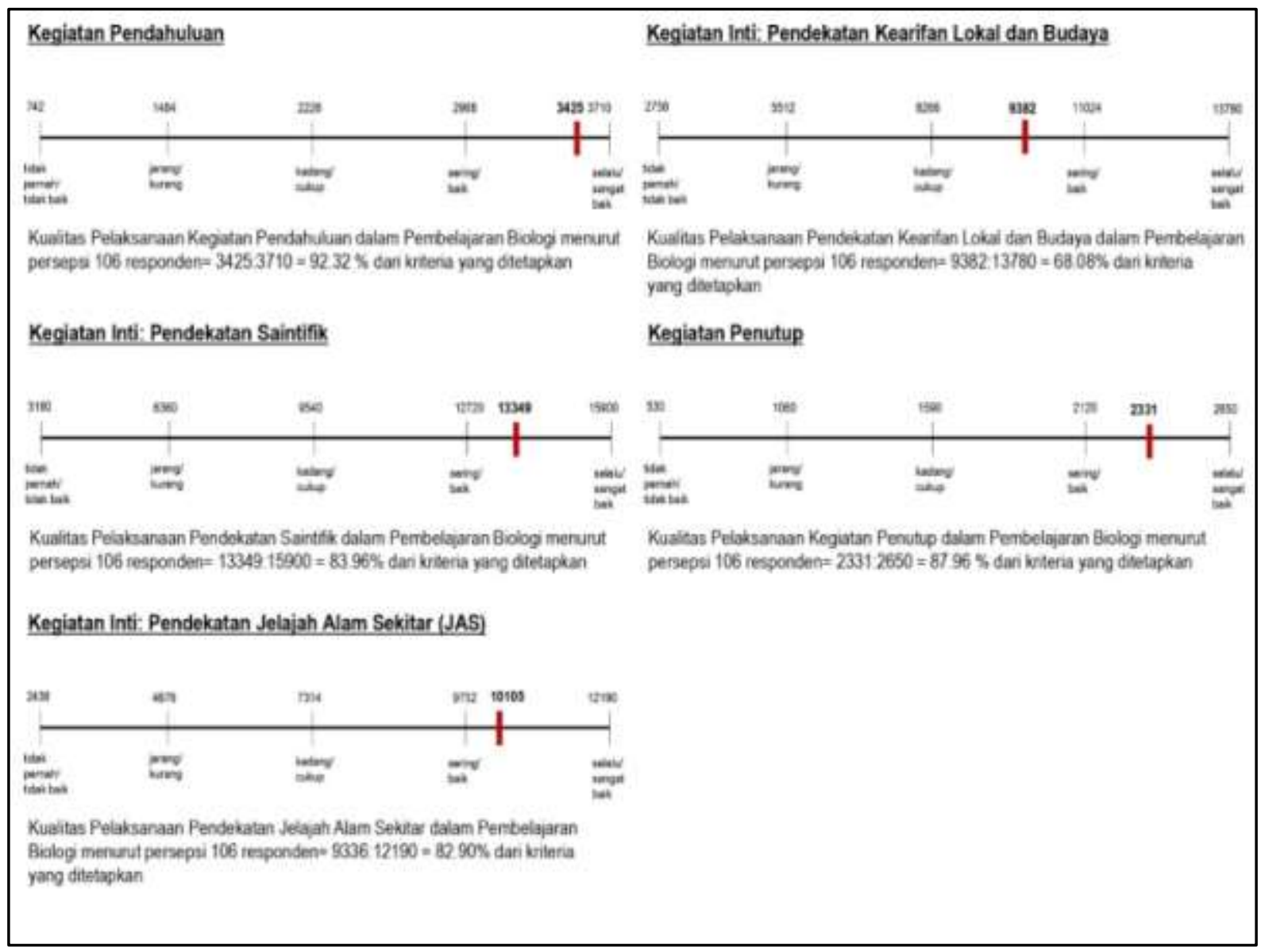

Gambar 2. Persepsi Peserta didik terhadap Kualitas Pelaksanaan Kegiatan Pembelajaran tiap tahap (Pendahuluan, Inti, dan Penutup) SMA Swasta di Kabupaten Purworejo 
Berdasarkan Gambar 2, SMA Swasta di Kabupaten Purworejo lebih cenderung menggunakan Pendekatan Saintifik sesuai arahan Kurikulum 2013 dan Pendekatan Jelajah Alam Sekitar.Pendekatan Saintifik (scientific) dikenal juga dengan istilah pendekatan ilmiah (Maryani and Fatmawati, 2018), di mana pendekatan ini selalu dilalui dengan kegiatan ilmiah, seperti mengamati (observing), menanya (questioning), mengumpulkan informasi/mencoba (experimenting), mengasosiasi (associating), dan mengomunikasikan (communicating) (Nugroho, 2014). Dalam pelaksanaanya, tidak semua materi dilakukan dengan Pendekatan Saintifik karena tergantung situasi dan kondisi peserta didik serta sekolah.

Pendekatan Jelajah Alam Sekitar (JAS) memanfaatkan lingkungan di sekitar tempat tinggal peserta didik (peserta didik) baik itu lingkungan fisik, sosial, teknologi, dan budaya yang dijadikan obyek belajar sendiri dan dipelajari dengan kerja ilmiah (Alimah and Aditya, 2016) di mana dalam pelaksanaannya dapat dilakukan eksplorasi baik pengamatan di luar kelas maupun melalui teknologi seperti internet atau sumber lain (Adinugraha, 2018a), serta dilakukan dengan kerja ilmiah serta pelaksanaannya berpusat pada peserta didik (Ismartoyo and Indriasih, 2013).

Pendekatan Kearifan Lokal dan Budaya masih tergolong baru karena dalam buku cetak yang diterbitkan juga belum banyak menyinggung akan hal ini. Padahal, banyak kajian-kajian yang bisa diambil seperti kajian etnobiologi dan kajian etnopedagogi yang ada di sekitar tempat tinggal peserta didik. Pembelajaran Biologi bisa sebagai pioner pembelajaran yang berakar pada nilai-nilai luhur budaya bangsa tanpa mengurangi kompetensi pelajaran Biologi yang harus dimiliki peserta didik. Pembelajaran Biologi terkadang mengambil contoh keanekaragaman hayati di luar Indonesia, padahal di sekitar tempat tinggal peserta didik banyak dijumpai. Sebagai contoh, di Purworejo terdapat kambing Peranakan Etawa, Durian, dan Manggis Kaligesing.

Berdasarkan gambaran di atas, maka kesimpulan pada sub bab ini adalah Pendekatan Pembelajaran Biologi yang dilakukan di SMA Swasta se-Kabupaten Purworejo adalah Pendekatan Saintifik dan Pendekatan Jelajah Alam Sekitar sedangkan Pendekatan Kearifan Lokal dan Budaya jarang digunakan atau tidak sama sekali. Salah satu faktor pendorong nilai hasil belajar adalah pendekatan pembelajaran. Namun, apabila dilihat pada Tabel 2, maka dapat dilihat bahwa nilai Ujian Nasional (UN) tidak bergantung pada pendekatan pembelajaran yang diterapkan di masing-masing sekolah. Sekolah dengan predikat nilai UN Biologi tinggi, persepsi peserta didik terhadap kualitas pembelajaran lebih rendah 
dibanding sekolah dengan predikat nilai UN Biologi rendah demikian juga sebaliknya. Hasil belajar UN yang menjadi tolok ukur pada penelitian ini tidak menjadi gambaran prestasi peserta didik secara keseluruhan. Hal ini karena UN hanya mengukur kemampuan kognitif saja. Meskipun bukan sebagai penentu kelulusan pada beberapa tahun terakhir, tetapi UN masih dianggap sebagai penentu mutu pendidikan (prestasi peserta didik dan hasil belajar peserta didik). Temuan pada penelitian ini adalah pendekatan pembelajaran yang sudah dilakukan tidak bisa membuat nilai UN Biologi juga baik. Hal ini karena ketiga pendekatan pembelajaran (Saintifik, Jelajah Alam Sekitar, dan Kearifan Lokal dan Budaya) lebih mengedepankan pengetahuan, keterampilan proses (saintifik), dan sikap. Pada Ujian Nasional hanya mengukur aspek kognitif (pengetahuan) tanpa menyertakan aspek afektif (sikap) dan psikomorik (keterampilan) (Silverius, 2010). Selain itu, nilai UN juga tidak menempatkan pembelajar (peserta didik) dalam porsi yang adil berdasarkan kronologi prestasi akademik yang sesungguhnya (Ali, 2010). Oleh karena itu, perlu dikembangkan penilaian terstandar yang mampu mengukur kemampuan peserta didik yang didasarkan pada 3 ranah (sikap, keterampilan, dan pengetahuan) yang juga berorientasi pada pendekatan pembelajaran yang disarankan oleh
Kurikulum bukan sebatas ranah kognitif saja.

2. Faktor yang Mendukung dan Menghambat Pembelajaran Biologi di SMA Swasta se Kabupaten Purworejo

$\begin{array}{ccc}\text { Berdasarkan } & \text { kuesioner } & \text { yang } \\ \text { diberikan kepada } & \text { responden } & \text { yang }\end{array}$
berjumlah 106 , ternyata $38.68 \%$ responden menyukai pembelajaran Biologi, $18.86 \%$ menyukai pelajaran matematika sedangkan sisanya menyukai pelajaran lain seperti: kimia, fisika, olaharaga, agama, dan kewirausahaan. Sepertiga lebih responden menyukai pembelajaran Biologi dengan alasan antara lain: menyenangkan dan menarik, tidak banyak berhitung, menyukai pelajaran tentang organisme dan karakteristiknya, mengejar cita-cita, serta guru yang mudah menyampaikan materi. Faktor-faktor tersebut yang mendorong peserta didik lebih menyukai pelajaran Biologi. Apabila diambil kesimpulan, faktor yang memengaruhi belajar Biologi peserta didik adalah dari proses pembelajarannya (guru dan pembelajaran yang menarik) serta dari dalam diri yaitu cita-cita dan motivasi. Minat peserta didik dalam belajar Biologi dapat memengaruhi hasil belajar Biologi. Apabila materi pelajaran yang dipelajari tidak sesuai dengan minat peserta didik, maka peserta didik tidak menjadi tidak tertarik dan enggan untuk belajar sehingga akan memengaruhi proses dan pencapaian hasil belajar (Berutu and Tambunan, 2018). 
Berdasarkan wawancara dengan guru Biologi, maka kendala yang dialami dalam pembelajaran Biologi adalah waktu dan kondisi kemampuan akademik peserta didik. Sarana memang juga dapat menghambat pembelajaran tetapi kreativitas guru dalam pembelajaran dapat mengatasi hal tersebut. Kondisi yang tidak bisa diprediksi terhadap kegiatan di sekolah menjadi salah satu penghambat berjalannya pembelajaran. Sebagai contoh, adalah pandemi Covid-19 ini. Namun, sebelum kondisi pandemi Covid-19 pun pembelajaran juga dapat terganggu apabila ada kegiatan insidental yang harus dilakukan baik oleh guru dan peserta didik. Kondisi sebagian besar peserta didik yang memiliki kemampuan akademik kurang juga menjadi tantangan tersendiri bagi guru untuk membuat pembelajaran menarik. Berkurangnya peminat terhadap SMA Swasta mengakibatkan jumlah peserta didik di SMA Swasta juga mengalami penurunan. Di Purworejo, terjadi pergeseran trend peminat peserta didik untuk lebih memilih SMA Negeri, SMK dan Madrasah dibandingkan SMA Swasta. Penurunan jumlah peserta didik ini secara tidak langsung juga akan memengaruhi kegiatan belajar mengajar.

Berdasarkan wawancara, empat dari lima guru Biologi di sekolah penelitian sudah tersertifikasi. Hal ini berarti kualitas guru Biologi SMA Swasta di Purworejo sudah baik. Sarana dan prasarana memang cukup sulit bagi sekolah swasta karena tentunya membutuhkan pemasukan dana dari peserta didik dan donatur. Penurunan jumlah peserta didik yang terjadi pada saat pengamatan juga menjadi salah satu faktor pemasukan bagi sekolah swasta. Namun, di tengah keterbatasan di beberapa SMA Swasta tersebut, guru-guru sangat kreatif, tidak mengeluh dengan keadaaan, serta saling mendukung satu sama lain dengan adanya MGMP Biologi.

Peningkatan mutu pengelolaan guru mata pelajaran dalam bentuk MGMP dapat melalui pembinaan program kerja yang mendukung pencapaian standar kompetensi kelulusan (SKL) dan peningkatan monitoring pembelajaran di kelas bisa menjadi solusi dalam peningkatan mutu pembelajaran (Siregar, 2016). Selain inovasi yang harus dilakukanoleh sekolah, Pemerintah Pusat dan Daerah harus terus mendukung dalam upaya eksistensi SMA Swasta sebagai sekolah yang membantu tersedianya layanan pendidikan bagi masyarakat.

\section{SIMPULAN DAN SARAN SIMPULAN}

Pendekatan Pembelajaran Biologi yang dilakukan di SMA Swasta seKabupaten Purworejo adalah pendekatan saintifik dan pendekatan jelajah alam sekitar sedangkan Pendekatan Kearifan Lokal dan Budaya jarang digunakan. 


\section{SARAN}

Pendekatan Keterampilan proses sains seperti pendekatan saintifik, pendekatan jelajah alam sekitar, dapat dijadikan sebagai rujukan dalam pembelajaran biologi dengan catatan guru mampu mengemas pembelajaran yang bukan bersifat transfer pengetahuan saja tetapi keterampilan dan sikap.

\section{UCAPAN TERIMA KASIH}

Terimakasih kepada LPPM Universitas Kristen Indonesia (UKI) Jakarta atas Hibah Penelitian Dosen dan Mahasiswa yang diberikan serta koordinasi dan bimbingannya sehingga penelitian ini bisa terlaksana. Terimakasih juga kepada sekolah penelitian, antara lain: SMA Bruderan Purworejo, SMA Pius Bakti Utama Bayan Purworejo, SMA Muhammadiyah Purworejo, SMA Islam Sudirman Bruno Purworejo, SMA Pancasila Purworejo, dan SMA Widya Kutoarjo Purworejo.

\section{DAFTAR PUSTAKA}

Adinugraha, F (2018a), 'Pendekatan Jelajah Alam Sekitar (Jas) Pada Mata Kuliah Sistematika Hewan', Pro-Life, 5(3), pp. 598-610. doi: 10.33541/prolife.v5i3.838;

Adinugraha, F (2018b), 'Tari Dolalak Sebagai Bentuk Pendekatan Kearifan Lokal Dan Budaya (Kalbu) Pada Mata Pelajaran Biologi'; EDUKA, Jurnal Pendidikan, Hukum, Dan Bisnis; 3(1). doi: 10.32493/eduka.v3i1.3803;
Agustina, P. \& A. S (2017), 'Analisis Keterampilan Proses Sains (KPS) Dasar Mahasiswa Calon Guru Biologi Pada Matakuliah Anatomi Tumbuhan (Studi Kasus Mahasiswa Prodi P. Biologi FKIP UMS Tahun Ajaran 2015/2016)', in Prosiding SNPS Seminar Nasional Pendidikan Sains, pp. 71-78;

Ali, M. N. (2010), 'Telaah tentang kibijakan ujian nasional dan kinerja sistem pendidikan nasional', Academica, 2(1), pp. 263-272;

Alimah, S. and Aditya, M. (2016), Jelajah Alam Sekitar: Pendekatan, Strategi, Model, dan Metode Pembelajaran Biologi Berkarakter untuk Konservasi, Semarang, Pendidikan Biologi UNNES;

Anggito, A. and Setiawan, J. (2018), Metodologi Penelitian Kualitatif, Sukabumi: CV Jejak;

Berutu, M. H. A. and Tambunan, M. I. H. (2018), 'Pengaruh Minat Dan Kebiasaan Belajar Terhadap Hasil Belajar Biologi siswa Sma Se-Kota Stabat', Jurnal Biolokus; 1(2), p. 109. doi: 10.30821/biolokus.v1i2.351;

Biro Komunikasi dan Layanan Masyarakat Kemdikbud (2016), 'Jendela Pendidikan dan Kebudayaan: Empat Perbaikan Kurikulum 2013', Kemdikbud;

Erayati, T. (2014), Pelaksanaan Kegiatan Belajar Mengajar oleh Guru pada Mata Pelajaran Ekonomi Kelas XI IPS 1 di SMA;

Hamdi, A. S. and Bahruddin, E. (2014), Metode Penelitian Kuantitatif: Aplikasi dalam Pendidikan, Yogyakarta: Deepublish;

Hanurani, H. (2019), 'Gambaran umum penguasaan materi ujian nasional tingkat SMA/MA mata pelajaran 
Biologi', JPPS (Jurnal Penelitian Pendidikan Sains), 9(1); pp. 17351739;

Idrus, M. (2010), 'Ujian Nasional Dalam Konsep Evaluasi Pendidikan', Millah, ed(khus), pp. 201-220; doi: 10.20885/millah.ed.khus.art12;

Ismartoyo and Indriasih, A. (2013), 'Penerapan Pendekatan Jelajah Alam Sekitar Pada Perkembangbiakan Tumbuhan Di Sekolah Dasar', Penerapan Pendekatan Jelajah Alam Sekitar Pada Perkembangbiakan Tumbuhan Di Sekolah Dasar, 17(1), pp. 254-266;

Lutvaidah, U. (2016), 'Pengaruh Metode dan Pendekatan Pembelajaran terhadap Penguasaan Konsep Matematika', Formatif: Jurnal Ilmiah Pendidikan MIPA, 5(3); pp. 279-285. doi: 10.30998/formatif.v5i3.653;

Maryani, I. and Fatmawati, L. (2018), Pendekatan Scientific dalam Pembelajaran di Sekolah Dasar, Sleman: Penerbit Deepublish;

Morissan (2012), 'Metode Penelitian Survei', p. 166;

Mukhroji (2015), 'Manajemen Sarana dan Prasarana Pendidikan', Insania, 16(1), pp. 53-64;

Nugroho, T. (2014), 'Pendekatan Scientific Model, Dan Strategi Pembelajaran Dalam Kurikulum 2013', Lingua Franca, 8, pp. 797-808;

Pieter, J. (2016), 'Pembelajaran Ipa Berbasis Kearifan Lokal Sebagai Solusi Pengajaran Ipa Di Daerah Pedalaman Provinsi Papua', Prosiding Seminar Nasional Pendidikan UNCEN Tahun 2016, (March 2016), pp. 44-54, doi: 10.5281/zenodo.840857;
Prasatyawan (2016), 'Manajemen Sarana dan Prasarana Pendidikan', 6, pp. 3446;

Pusat Penilaian Pendidikan Kemdikbud (2020), Laporan Hasil Ujian Nasional. Available at: https://hasilun.puspendik.kemdikbud.g o.id/;

Safari, P. (2015), 'Ujian Nasional Sebagai Cermin Mutu Pendidikan Dan Pemersatu Bangsa : National Exam As a Reflection for Quality of Education and a Nation Adhesive', Jurnal Pendidikan dan Kebudayaa, 21(2);pp. 101-114;

Santosa, T. I. and Siregar, T. (2017), 'Implementasi Kurikulum 2013 dalam Pembelajaran Kimia Kelas X SMA seKota Jayapura', Jurnal Ilmu Pendidikan Indonesia, 5(2); pp. 4959;

Setiawan, D., Melia, Y. and Rahayu, S. (2016), 'Faktor-faktor penyebab rendahnya hasil nilai ujian nasional (un) dari tahun 2015-2016 di smp negeri 1 sasak ranah pasisie; kabupaten pasaman barat', Jurnal Ilmiah Mahasiswa STKIP PGRI Sumbar; pp. 1-11;

Silverius, S. (2010), 'Kontroversi Ujian Nasional Sepanjang Masa', Jurnal Pendidikan dan Kebudayaan, 16(2), p. 194. doi: 10.24832/jpnk.v16i2.446;

Siregar, T. (2016), Analisis Faktor-faktor yang Mempengaruhi Hasil Ujian Nasional (UN) IPA di SMA Negeri 2 Tigi Kabupaten Deiyai Provinsi Papua, Unimed. Available at: http://digilib.unimed.ac.id/id/eprint/61 3 ;

Sugiyono, S. (2019), Metode penelitian kuantitatif, kualitatif dan $R \& D$, Bandung: Alfabeta; 
Syarifuddin, A. (2011); 'Penerapan Model Pembelajaran Cooperative Belajar Dan Faktor-Faktor Yang Mempengaruhinya',Ta'dib:Journal of Islamic Education (Jurnal Pendidikan Islam), 16(01), pp. 113-136. doi: 10.19109/tjie.v16i01.57;

Turdjai (2014), 'Pengaruh Pendekatan Pembelajaran terhadap Hasil Belajar Mahasiswa', Triadik, 15(2), pp. 1729, Available at: https://ejournal.unib.ac.id/index.php/tr iadik/article/download/2865/1373;

Verawati, N. N. S. V., Prayogi, S. and Asy'ari, M. (2014), 'Reviu Literatur Tentang Keterampilan Proses Sains', Lensa: Jurnal Kependidikan Fisika; 2(1), p. 194. doi: 10.33394/jlkf.v2i1.310. 